\title{
Technical Efficiency of Large Bank Production in Asia and the Pacific
}

\author{
Milind Sathye \\ University of Canberra, Australia
}

\begin{abstract}
This study investigates the efficiency of large commercial banks in Asia and the Pacific region. In particular, the overall technical efficiency, pure technical efficiency and scale efficiency has been estimated, the factors (including, the environmental factors) that influence efficiency of banks in the region have been explained and the mean efficiency of large banks in different countries of the region has been compared. The study found that when the national frontier was expanded to regional frontier, the efficiency scores declined, the environmental variables had significant influence on efficiency scores and developed countries showed pure technical efficiency score significantly higher than the less developed countries. Hence, going by the global advantage hypothesis a surge in mergers and acquisitions of banks in this region is predicted (JEL: O2, G2, G21, G28, E58, E61, F33, L5).
\end{abstract}

Keywords: bank efficiency, data envelopment analysis, Asia-Pacific.

\section{Introduction}

This paper has three objectives (1) to estimate the overall technical efficiency (TE), pure technical efficiency (PTE) and scale efficiency (SE) of large commercial banks in the Asia-Pacific region (2) to explain the factors (in particular, the environmental factors) that influence efficiency of banks and (3) to compare the mean efficiency of large banks in different countries of the region.

There are several reasons why estimating banking efficiency across the Asia-Pacific region is important. Firstly, the primary goal of banking deregulation in many countries was to improve efficiency. If efficiency is raised, the improved resource allocation could result in price reductions and /or service expansion for consumers. For example, in the Australian context, the Financial System Inquiry (1997) estimated that

${ }^{*}$ The author would like to thank the editor and the reviewers for their comments.

(Multinational Finance Journal, 2005, vol. 9, no. 1 \& 2, pp. 1-22)

(C) Multinational Finance Society, a nonprofit corporation. All rights reserved. DOI: $10.17578 / 9-1 / 2-1$ 
a 10 percent improvement in efficiency could lead to a saving of $\$ 4$ billion per year.

Secondly, the banking markets of different countries are becoming increasingly integrated. Such wider integration of international financial markets is associated with certain risks like that of a contagion. Bekaert et al. (2002) found that during the Asian crisis period the measures of contagion, increased by economically meaningful magnitudes suggesting increased economic regional integration during this time. Dungey and Martin (2001) using a different methodology find similar results. Buch and Henrich (2001) also support this view. Given this integration and the associated risks and the predominant role of banking sector in any economy, it is important to know, not only whether banks in a country are efficient but also how their efficiency compares with banks across countries. Banking efficiency is one of the indicators of health and stability of financial system in any country.

Thirdly, while there are many studies of bank efficiency in Europe and the U.S., the interest in banking efficiency in the region has just started. Berger and Humphrey (1997) state that the studies that have compared efficiency levels across countries relate to developed countries. There is no study in the literature that measures efficiency across Asia and the Pacific, an important region which consists of not only the developing economies but also the developed and the former 'Asian tiger' economies. The sample includes countries from these three groups. Hence, researchers in the developed world will get added insights in the bank efficiency framework from this study.

A knowledge of the factors that influence efficiency (in particular, the environmental factors) is important in the context of mergers and acquisitions (M\&As) among very large financial institutions, which are becoming more frequent in markets around the world. In particular, there is a trend towards cross-border M\&As. Berger et al. (2000) found that such cross-border penetrations are usually performed via M\&As, rather than via opening new branch offices. Their global advantage hypothesis states that institutions from one or a few nations are more likely to expand across borders-if the institutions from these nations are much more X-efficient than those from other nations.'

Some Australian banks already have a presence in the region and others are exploring possibilities of spreading activities there. A study of the comparative efficiency of banks, which also reveals the possible targets for M\&As, may be of interest to these banks. Further, as stated by Berger and Humphrey (1997), how environmental variables affect 
cross-country efficiency is an important issue, which is yet to be addressed in the international banking efficiency literature.

A comparative position of banking efficiency in different countries is important for the political authorities since competitiveness of the national banking industry is an issue of great concern. Hence, most countries are likely to take a strong interest in the development of that industry. This study gives comparative position of the national and regional efficiency scores, which the policy makers may find useful to benchmark domestic banking industry. Further, as already stated above in the context of cross border M\&As, most efficient banks will have a competitive edge. Dietsch and Lozano-Vivas (2000) state 'to predict the effects of the expected increase in cross-border competition, it is important to know how different or similar current banking performances are in different countries'.

For estimation of efficiency, a linear programming technique of data envelopment analysis (DEA) has been used. Regression is used to explain the factors that affect efficiency of banks in the region and multivariate analysis of variance (MANOVA) has been used to compare the banking efficiency across the region. The paper is organized as follows. The next section provides literature review on international comparisons of efficiency in banking. Section III describes the data sources and outlines the methodology. Section IV presents the results. Conclusions are discussed in the last section.

\section{Literature on International Banking Efficiency}

A number of studies have applied DEA to the question of efficiency in banking. Berger and Humphrey (1997) provide a comprehensive review of banking efficiency studies. However, only six studies so far have compared banking efficiency differences across countries. Four of these used non-parametric approaches, while two used parametric approaches. Berg et al. (1993) used DEA to explain differences in banking efficiency between three Scandinavian countries (Norway, Sweden and Finland). Initially, they constructed a frontier for each country and thereafter a 'common' frontier to work out efficiency scores and compare results across countries. By adding Denmark to the above sample, Berg et al. (1995) did a follow up study.

The same four countries were investigated by Berhendahl (1995) using mixed optimal strategy. Fecher and Pestieau (1993) as well as 
Pastor, Perez, and Quesada (1997) applied a distribution free approach (DFA) and DEA analysis to 11 OECD countries and eight developed countries respectively. These studies constructed a common frontier by pooling cross-country data. The results of Fecher and Pestieau (1993) were opposite to those obtained in earlier studies of Berg et al. (1993 and 1995). Allen and Rai (1996) use DFA and stochastic frontier approach (SFA) for a systematic comparison of X-inefficiency measures across 15 developed countries under different regulatory environments. In a recent study, Dietsch and Lozano_Vivas (2000) estimate efficiency of French and Spanish banks separately as well as by constructing a 'common' frontier, using distribution free approach. They include environmental variables in the model to estimate efficiency and find that differences between efficiencies are substantially reduced and thus demonstrate the influence of environmental variables on efficiency scores between two countries.

The added value of this paper is that it (1) provides banking efficiency estimates for hitherto unexplored region (2) tests the effect of environmental variables based on a large sample (drawn from 17 countries of the region with 342 cases) and (3) compares banking efficiency in developed (high-income) and developing (low to medium income) countries (for the first time) that gives some interesting insights for further studies in this area.

\section{Methodology and Bank Financial Data}

Many different methods are available for estimating efficiency frontiers. The two principle methods are: (a) DEA (a non-parametric technique) and (b) stochastic frontier analysis (a parametric technique). In this study, DEA has been used to calculate efficiency scores. The ability of the DEA to identify possible peers or role models as well as simple efficiency scores gives it an edge over other methods. Secondly, literature review shows that it was the preferred method in most cross-country studies of this type. Thirdly, as Berger and Humphrey (1997) state one of the major advantages of DEA is that it does not require the explicit specification of the form of the underlying production relationship. Fried and Lovell (1994) have given a list of questions that DEA can help to answer.

DEA, was initially developed by Charnes, Cooper, and Rhodes (1978) to evaluate the efficiency of public sector non-profit 
organizations. Sherman and Gold (1985) were the first to apply DEA to banking. DEA calculates the relative efficiency scores of various Decision-Making Units (DMUs) in a particular sample. The DMUs could be banks or branches of banks. The DEA measure compares each of the banks/branches in that sample with the best practice in the sample. It tells the user which of the DMUs in the sample are efficient and which are not.

The unit of analysis in this study is a bank. Consider $N$ banks (DMUs), each producing $m$ different outputs using $n$ different inputs. The efficiency of the DMU is measured as follows:

$$
h_{s}=\sum_{i=1}^{m} u_{i} y_{i, s} / \sum_{j=1}^{n} v_{j} x_{j, s}
$$

where $y_{i, s}$ is the amount of the $i$ th output produced by the sth DMU, $x_{j, s}$ is the amount of the $j$ th input used by the $s$ th DMU, $u_{i}$ is the output weight, $v_{j}$ is the input weight, $i$ runs from 1 to $m$ and $j$ runs from 1 to $n$. This efficiency ratio $\left(h_{s}\right)$ is then maximized subject to the constraints:

$$
\sum_{i=1}^{m} u_{i} y_{i, r} / \sum_{j=1}^{n} v_{j} x_{j, r} \leq 1,
$$

for $r=1,2, \ldots, N, u_{i} \geq 0$ and $v_{j} \geq 0$. The inequality in (2) ensures that the efficiency ratios for the other DMUs cannot exceed one, while the second inequality requires that the weights are positive. The weights for each output and input are determined so that each DMU maximizes its own efficiency ratio. Any other set of weights produces a lower efficiency score. In other words, DEA gives the benefit of doubt to each DMU when calculating the efficiency ratios.

This functional linear program can be transformed into an ordinary linear program as follows:

$$
\max h_{s}=\sum_{i=1}^{m} u_{i} y_{i, s}
$$

subject to

$$
\sum_{i=1}^{m} u_{i} y_{i, r}-\sum_{j=1}^{n} v_{j} x_{j, r} \leq 0
$$




$$
\begin{gathered}
\sum_{j=1}^{n} v_{j} x_{j, s}=1 \\
u_{i} \geq 0 \text { and } v_{j} \geq 0
\end{gathered}
$$

for $r=1,2, \ldots, N$. Or the dual the dual problem as follows:

subject to

$$
\min \beta_{s}
$$

$$
\begin{gathered}
\sum_{r=1}^{n} \phi_{r} y_{i, r} \geq y_{i, s} \\
\beta_{s} x_{j, s}-\sum_{r=1}^{N} \phi_{r} x_{i, r} \geq 0
\end{gathered}
$$

for $i=1,2, \ldots, m, j=1,2, \ldots, n, \phi_{r} \geq 0$, and $\beta$ free.

The variable $\mathrm{s}$ is the overall technical efficiency and must lie between zero and one. The linear programming problem outlined in (5) and (6) assumes constant returns to scale (CRS). The overall technical efficiency can be divided into pure technical and scale efficiency. To accomplish this result, it is necessary to solve the linear programming problem in (5) and (6) after imposing the restriction that sum of the $\phi_{s}$ from $s=1$ to $N$ equals one, which allows for variable returns to scale (VRS). Three measures of efficiency, the CRS technical efficiency, the VRS or pure technical efficiency and the scale efficiency are obtained. Readers interested in the details of the various frontier measurement techniques are encouraged to consult the works of Banker et al. (1989), Bauer (1990), and Seiford and Thrall (1990), Aly and Seiford (1993) etc. There are a number of software options for running DEA. This study uses the software (DEAP) developed by Coelli (1996) to calculate the efficiency scores of banks in the sample.

The definition and measurement of banking inputs and outputs has been a matter of long-standing debate among researchers. For defining inputs and outputs, prior research studies adopt either the intermediation or production approach. Under the production approach, a financial institution is defined as a producer of services for account holders, that is, they perform transactions on deposit accounts and process documents such as loans.

Hence, according to this approach, the number of accounts or their 
related transactions best measures output. Sherman and Gold (1985), Ferrier and Lovell (1990), and Fried el al. (1993) follow this approach. The inputs include the number of employees and physical capital. Under the intermediation approach, financial intermediaries are institutions that convert and transfer financial assets between surplus units and deficit units. For this approach, output is defined as the dollar value of deposits and loans while inputs include labor, fixed assets and equipment and loanable funds.

This study uses the intermediation approach. Berger and Humphrey (1997) state that 'this approach has been found to be more relevant for financial institutions...' The inputs used are deposits and financial capital and the outputs are loans and net interest income. This selection of inputs and outputs follows the theory of bank cost and production function and the work of Aly et al. (1990) and Hancock (1986), wherein the authors develop a methodology based on user costs to determine the outputs and inputs of a banking firm. The inputs and outputs used in this study have also been used in earlier studies, for example, Avkiran (1999), Chen and Yeh (1998), Ayadi et al. (1998), and Berg et al. (1993). It is possible to include additional inputs and outputs than those used in this study but availability of data restricted choice of inputs and outputs as it did in similar other studies. As price data was not available, the allocative and cost efficiencies could not be worked out.

Efficiency scores have been worked out under assumptions of CRS, and VRS. The latter, seems to be the most natural assumption since the degree of scale economies in banking is a classical issue and since the efficiency scores obtained are then more robust to mis-specification. However, Berg et al. (1993) state that 'when a VRS is used most large banks will appear as fully efficient, possibly only for lack of comparable truly efficient banks'. With CRS assumption one can compare large banks with not so large banks in the sample and this avoids them to appear as artificially efficient. Since each of the assumption has its advantages, both the assumptions were used in this study.

After working out efficiency estimates (TE, PTE, and SE), regression analysis was employed to study relationship between efficiency and a set of bank specific and environmental variables. Thereafter, MANOVA was used to study whether efficiency differences across three groups of countries (high income, medium income and low income) are significant.

The data published by the Asia Week (2000) about regions 500 largest commercial banks for the year 2000 has been used. Asia Week 
TABLE 1. Descriptive statistics (US \$ million)

\begin{tabular}{lrrrrr}
\hline & $N$ & Minimum & Maximum & Mean & $\begin{array}{c}\text { Standard } \\
\text { deviation }\end{array}$ \\
\hline Loans & 458 & 37 & 375625 & 15428 & 44724 \\
Net Interest Income & 458 & 1 & 8413 & 379 & 924 \\
Deposits & 458 & 80 & 435494 & 18225 & 49844 \\
Capital & 458 & 4 & 27919 & 1310 & 3344 \\
Total assets & 458 & 233 & 680096 & 25097 & 3413 \\
\hline
\end{tabular}

TABLE 2. Mean Values of Inputs and Outputs Used by Country (US \$ million)

\begin{tabular}{|c|c|c|c|c|c|}
\hline Country & $N$ & Loans & $\begin{array}{l}\text { Net interest } \\
\text { income }\end{array}$ & Deposits & Capita \\
\hline Australia & 22 & 17656.73 & 613.07 & 16066.00 & 1658.71 \\
\hline Bangladesh & 11 & 600.00 & 13.18 & 880.54 & 37.09 \\
\hline China & 21 & 34163.71 & 765.57 & 47267.81 & 3256.85 \\
\hline Hong Kong & 26 & 6771.11 & 352.50 & 12534.65 & 1191.50 \\
\hline India & 55 & 1442.54 & 99.60 & 3046.83 & 198.92 \\
\hline Indonesia & 18 & 171.88 & 24.94 & 353.94 & 51.16 \\
\hline Japan & 138 & 33906.21 & 715.81 & 38325.42 & 2433.34 \\
\hline Macau & 6 & 690.00 & 24.83 & 970.33 & 83.33 \\
\hline Malaysia & 31 & 2673.19 & 112.87 & 3567.70 & 351.70 \\
\hline New Zealand & 7 & 6322.71 & 173.57 & 4971.14 & 376.28 \\
\hline Pakistan & 11 & 901.45 & 50.81 & 1738.90 & 54.27 \\
\hline Philippines & 25 & 1099.36 & 69.96 & 1618.52 & 279.40 \\
\hline PNG & 2 & 164.50 & 27.00 & 290.50 & 24.00 \\
\hline Singapore & 8 & 15039.63 & 448.37 & 17848.25 & 2470.62 \\
\hline South Korea & 15 & 16985.00 & 559.73 & 18979.40 & 1306.66 \\
\hline Sri Lanka & 6 & 601.33 & 43.83 & 815.00 & 66.00 \\
\hline Taiwan & 47 & 8081.93 & 206.29 & 9728.34 & 1004.36 \\
\hline Thailand & 9 & 9852.44 & 122.44 & 11324.22 & 844.11 \\
\hline Total & 458 & 15428.48 & 379.59 & 18225.82 & 1310.40 \\
\hline
\end{tabular}

has published data after converting it into U.S. dollar equivalent and has classified banks with assets in excess of U.S. \$ 229 million as large banks. The data set was screened and banks, in respect of which data on some of the inputs or outputs was missing, were excluded from sample. Thus, the final sample consists of data of 458 banks in 18 countries of the Asia-Pacific region. 


\section{Results}

\section{A. Descriptive Statistics}

Tables 1 and 2 present descriptive statistics about the banks in the sample. Given the very high spread of data, several measures as outlined in subsequent paragraphs were taken to normalize the data.

\section{B. Efficiency Estimates}

\section{Efficiency estimates under two different frontiers}

The mean efficiency scores of banks in each of the countries included in the sample were calculated with inputs and outputs indicated earlier and running a DEA program. Three types of scores -TE, PTE and SE were generated using the BCC model described by Coelli (1996). While working out efficiency estimates, two separate frontiers, national and regional (all countries put together) were constructed. The results are recorded in table 3.

The above table shows that the mean scores by country decline as the frontier is widened from national to regional. Earlier cross-country studies that use a 'common' frontier find identical results. Of particular interest is the case of Thailand, the country where the Asian crisis started. The national frontier shows high efficiency scores but at the regional frontier, the scores of TE and PTE fall sharply. The high efficiency score of Thailand need not come as a surprise. As stated by Berger et al. (2000) Swedish banks tended to be measured as superior performers, despite the fact that these banks suffered a crisis in the early 1990 s requiring substantial government intervention. What appear to be very efficient banks at the national frontier may not remain so when cross-country frontiers are constructed. If policy makers benchmark domestic banks with banks in other countries, their relative efficiency will be known. This could help prudential supervisors to suitably adjust policies so as to maintain a sound and healthy banking system. National frontiers alone could be misleading.

Ten countries show TE and PTE scores lower than the mean of the region, while six countries have scale efficiency scores lower than the regional score. The TE is highest among large banks in PNG and New Zealand and lowest in China and Hongkong. The countries in the top quartile of TE are PNG, New Zealand, Indonesia and Australia. 


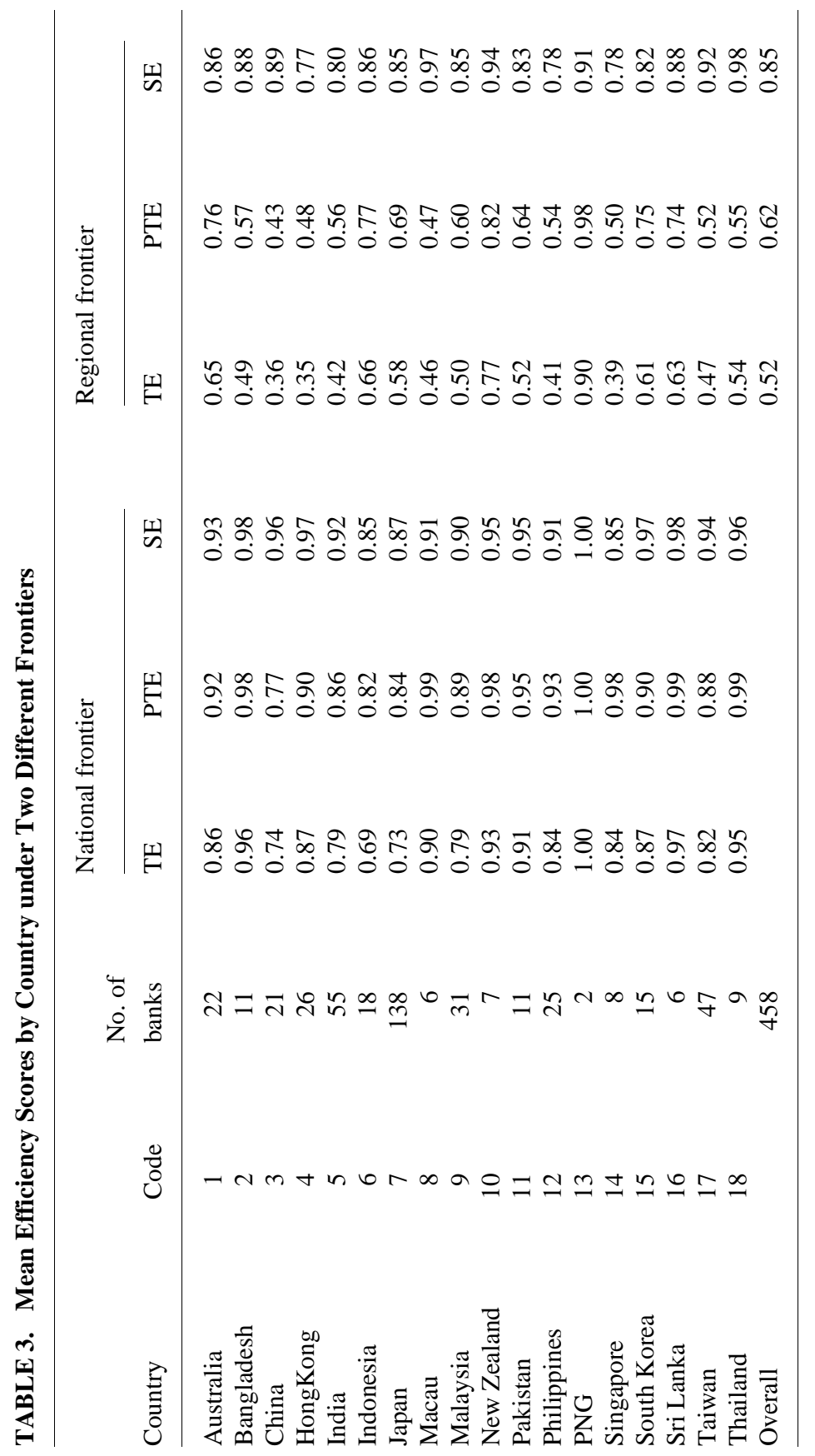


Table 4. Mean Efficiency Scores Grouped by Bank Profitability

\begin{tabular}{lccc}
\hline & TE & PTE & SE \\
\hline Lowest Profitability Quartile (Q1) & 0.502 & 0.588 & 0.867 \\
Next to lowest quartile (Q2) & 0.515 & 0.627 & 0.835 \\
Next to Highest profitability quartile (Q3) & 0.465 & 0.565 & 0.825 \\
Highest profitability quartile (Q4) & 0.551 & 0.675 & 0.835 \\
Overall & 0.509 & 0.614 & 0.841 \\
\hline
\end{tabular}

Bank-level efficiency data (available on request from the author) showed that seven banks (3 Indonesian, 3 Japanese and 1 PNG) are on the 'grand' efficiency frontier with CRS efficiency of 1.000 . Twenty-seven banks are on VRS efficiency frontier and ten banks are on scale efficiency frontier. This means that the remaining banks have some inefficiencies either pure technical or scale that these banks need to remove to achieve best practice. Four Australian banks viz., National Australia Bank, Commonwealth Bank of Australia, Westpac and Citi Bank were on the VRS efficiency frontier. This indicates that pure technical inefficiencies (under utilisation of inputs) were not found among these banks. None of the Australian banks is found on scale efficiency frontier, which indicates that scale or output inefficiencies exist. Ferrier (1997) states 'A DMU may be scale inefficient if it exceeds the most productive scale size (thus experiencing decreasing returns to scale) or if it is smaller than the most productive scale size (thus failing to take full advantage of increasing returns to scale)'. At the national level, this means that there is scope for some large banks showing scale inefficiencies to achieve optimum size.

\section{Large bank efficiency measures grouped by profitability}

Table 4 gives information on overall technical, pure technical and scale efficiency grouped in to four quartiles for the total sample of 401 banks. 57 banks were required to be excluded for this analysis, as the data about profitability of these banks was not available.

Several observations can be made. First, scale efficiency measured about 84 per cent. The lowest quartile has highest scale efficiency among the four quartiles while the least is for Q3. There doesn't appear to be a large difference in scale efficiency levels in the four quartiles as is the case with PTE. The evidence seems to indicate that though scale inefficiency is significant, it is PTE that seems to have more influence 
on bank profitability. This finding is similar to what Miller and Noulas (1996) found in their study of large U.S. banks. Secondly, pure technical efficiency is lower than scale efficiency in all the quartiles. Notably PTE was highest in Q4 meaning highest profitable banks are technically more efficient than banks in the other three quartiles. Thirdly, looking at the TE and PTE, some evidence to suggest that the most profitable banks are technically the most efficient can be found. The finding contrasts with those of Kwast and Rose (1982) who find no compelling evidence 'that high-profit banks are characterized by greater operating efficiency than their low-earnings counterparts'. This difference in finding may suggest that by the end of the last decade, the industry became more competitive, strengthening the link between profitability and efficiency.

\section{Effect of Environmental Variables on Efficiency Scores}

\section{Regression Analysis}

Many empirical studies in the past, for example, Field (1990) and Lucey (1995) have examined the interaction between efficiency and other bank specific variables like total assets, profitability, market power etc. However, Berger et al. (2000) suggest that the measured X-efficiency would vary considerably if economic environmental variables; for example, variables measuring banking market conditions, market structure and regulation are included in the model. Hence, in this study, efficiency was regressed on various bank specific variables as well as environmental variables. The effects of bank size, profitability, market power, and environmental factors on TE were considered. This is because TE is a product of PTE and SE and thus embodies both these types of efficiencies. Bank size is measured by total assets and bank profitability by ratio of return on assets. Some aspects of market power were captured with the ratio of bank deposits to total deposits in the country within which the bank operates. Following earlier studies, for example, Berger et al. (2000), Dietsch and Lozano-Vivas (2000), the environmental variables included are population density (population per square kilometer), per capita income, equity to assets ratio, and intermediation ratio (loans/deposits). The latter two variables serve as control for regulation. There could also be factors like ownership of banks (foreign vs domestic) affecting efficiency. However, given that information about these aspects for each of the countries could not be readily obtained, this aspect has been ignored. 
No sign was postulated for the size variable. U.S. studies indicate that the technical efficiency measure is positively related to size, however, a study by Molyneux et al. (1996) in UK shows otherwise. Profitability was expected to have a positive relation to efficiency for obvious reasons. Market power variable is expected to have a positive sign according to the structure-conduct-performance hypothesis. Coming to the environmental variables, as higher per capita income is likely to enhance capacity to borrow and repay loans -a major banking output- it will favorably impact the input-output ratio, that is, overall technical efficiency. Hence a positive sign is expected for this variable. Loan to deposits ratio (LDR) captures the credit creation by banks and a larger credit creation results from increased efficiency. Hence, this variable is expected to have a positive sign. Capital to assets ratio (CAR) is expected to have a negative sign, given that many banks are shedding there excess capital to increase profitability and shareholder value. No sign is postulated for population density variable. Generally, high density may lead to higher demand for services and hence increased output and efficiency. However, many developing countries like India and China have high population density characterized by poverty. In such cases lower capacity to repay, may hamper production of loans and hence efficiency.

For the purpose of regression, data of 377 banks was used. The remaining banks had to be excluded, as data for some of the variables included in the regression was not available in respect of these banks. The data was then screened.

Outliers outside \pm 3 standard deviations (30 cases) were identified using case-wise diagnostic procedures available in SPSS. Mahalanobis test showed five multivariate outliers (at $p<0.001$, with 7 d.f. and critical value of 24.32). All the outlier cases were deleted leaving 342 cases for multiple regression analysis. Some of the variables required $\log$ transformation to achieve normality. After the transformations, the skewness and kurtosis values in respect of all the variables were below \pm 1.96 (except for LOGPOP with kurtosis $=2.90$ ) signifying that normality was not a serious concern. Hair et al. (1998) state that for a calculated value exceeding \pm 1.96 which corresponds to a 0.05 error level, normality could be a concern. The normal probability plot showed that the residuals line closely follows the diagonal, further confirming that normality was not a concern. The plot of standardized residuals against standardized predicted values showed that homoscedasticity was not a concern (all values were in the range of \pm 3 ) and points were randomly distributed without any discernable pattern. 
Table 5. Regression Results

\begin{tabular}{lcrl}
\hline Variable & $\begin{array}{l}\text { Unstandardized } \\
\text { coefficients }\end{array}$ & t-values & VIF \\
\hline Constant & -7.42 & -1.19 & \\
LOGASS & $-1.97 * *$ & -9.11 & 2.83 \\
LOGROA & $8.11^{* *}$ & 2.47 & 2.04 \\
LOGDEP & $1.32^{* *}$ & 5.91 & 2.57 \\
LOGPOP & $-1.42^{* *}$ & -7.92 & 1.74 \\
LOGLDR & $0.27 * *$ & 24.79 & 1.88 \\
LOGCAR & $-0.16^{* *}$ & -28.95 & 1.47 \\
GDP & $2.49^{* *}$ & 7.59 & 4.25 \\
\hline
\end{tabular}

Notes: $N=342$, Adjusted $R$-square $=0.88, F=376.73$ and $p=0.000 . * *$ Significant at the $5 \%$ level.

The results of the regression are presented in table 5. Bank profitability, is significantly positively related to technical efficiency. Thus, more profitable banks have higher technical efficiency. Bank size variable shows a significant negative relation. These results are in line with the findings of Miller and Noulas (1996) study. The variable market power (LOGDEP) exerts positive and significant influence, which means that banks with more market power, as measured by the share of total country deposits, possess higher technical efficiency. The result of the influence of environmental variables is interesting. As expected per capita income has a significant positive influence on TE. This means that large banks in richer countries have higher TE. LOGLDR has a positive sign and LOGCAR has a negative sign as was expected. All the four environmental variables have a significant impact on efficiency scores. Hence, it is important to include these variables in efficiency analysis of banks. These findings are similar to those in the study by Dietsch and Lozano-Vivas (2000).

\section{Efficiency scores with and without environmental variables}

As the regression showed that environmental variables significantly affect efficiency, the efficiency scores were calculated again using DEA for 377 banks for which data of the two outputs and six inputs (including four environmental variables as inputs) was available. The results are presented in table 6 .

The table shows that the mean technical efficiency score is much larger when environmental variables are included in the analysis. Thus, 


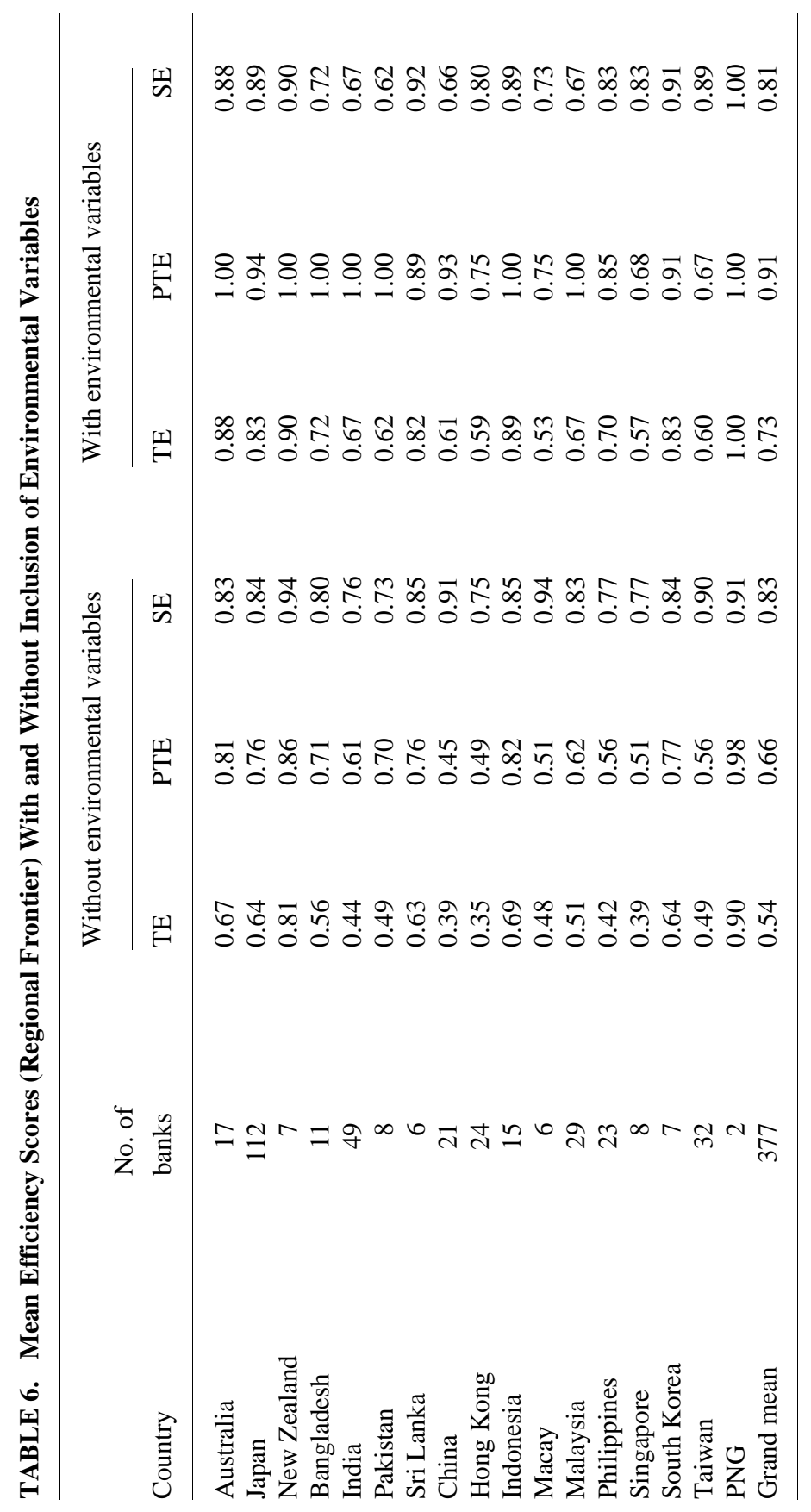


environmental variables do significantly affect efficiency scores and excluding them from the analysis could be misleading.

\section{Comparative Position on Efficiency}

Next the three efficiency scores (TE, PTE and SE), obtained by inclusion of environmental variables, were compared by grouping the countries into three categories. Following the World Bank (2000) classification, the three groups are: the developed countries (high income) viz., Australia, New Zealand, Japan, Hong Kong, Macau, Singapore and Taiwan (group 1), medium income countries like Sri Lanka, Malaysia, South Korea, PNG and Philippines (group 2) and developing countries (low income), which includes India, Pakistan, Bangladesh, China and Indonesia (group 3).

To test whether the mean efficiency scores are significantly different from each other MANOVA was used. Hair et al. (1998) state that for the multivariate test procedures of MANOVA to be valid, three assumptions must be met. These are (1) the variance-covariance matrices must be equal for all treatment groups (2) the set of p-independent variables must follow a multivariate normal distribution and (3) the observations must be independent. The region-wise distribution of 342 cases used for regression was 194, 57 and 91 in groups 1, 2 and 3, respectively. As a preliminary check for equality of variance-covariance matrices, sample variances for each dependent variable are compared across the three groups. The largest variance ratio is about 6.29 to 1 for SE (ratio of largest to smallest variance) and the sample sizes are relatively equal 3.40 and 1 (largest to smallest cell size).

Tabachnick and Fidell (1996) state that where the largest to smallest variance ratio is less than 10 to 1 and the sample sizes are relatively equal (within a ratio of 4 to 1) use of MANOVA is not invalidated. However, Stevens (1992) states that for robustness of MANOVA, the ratio of smallest to largest sample size should be less than 1 . Hair et al. (1998) also support this 1.5 rule. We have used this stricter rule to make the three groups relatively equal. To equalize the sample sizes, Tabachnick and Fidell (1996) recommend 'random deletion of cases'.

Hence, data was arranged in groups and every second case from group 1 and thereafter every sixth case and every tenth case from group 3 , was deleted till we had banks in the three groups in the ratio of 81:57:81. This brings the ratio of largest and smallest group size within the 1.5 rule and hence we could expect results that are robust. 
Tabachnick and Fidell (1996) state that if sample sizes are equal, robustness of significance test is expected, disregard the outcome of Box's M test...' Data screening revealed that skewness and kurtosis of all the groups was below \pm 1.96 . One univariate outlier case (outlier outside 3 standard deviations, case no. 166 of SE) was detected and omitted. Checks using Mahalanobis distance did not reveal any multivariate outliers.

All the values for Cook's distance for the dependent variables (PTE and SE) were less than 1 indicating that there was no case with substantial influence. The second assumption to test is that of multivariate normality. According to Tabachnick and Fidell (1996) 'even with unequal $n$ and only a few DVs (dependent variables), a sample size of about 20 in the smallest cell should ensure robustness'. In this study, the smallest cell has a size of 57 , hence multi-variate normality was not a concern.

As for the univariate normality we have the protection of the central limit theorem. Independence of observations was established based on substantive knowledge. Hair et al. (1998) state there are no tests available that can detect dependence with absolute certainty. Another issue in MANOVA is that of multicollinearity among the dependent variables. Norusis (1993) states that there is no reason to use the MANOVA procedures if the dependent variables are not correlated. However, as stated by Hair et al. (1998) the dependent variables should not have high multi collinearity. The dependent variable TE is a product of PTE and Scale. When correlation among dependent variables is high ( $r=+0.80$ for TE and PTE), Tabachnick and Fidell (1996) recommend deletion of the redundant variable. Accordingly, the variable TE was deleted from the analysis and PTE and SE (which show significant but negative correlation $(r=-0.63))$ were used as dependent variables in subsequent analysis.

Due to the various adjustments required to perform MANOVA, the number of banks used in the analysis were 81, 57 and 80, for a (total 218 banks. MANOVA yielded results which show that the mean vectors of efficiency of the three groups are not equal; see table 7.1. Thus, there is significant difference between the efficiency of the three groups of countries. Univariate tests show that the significant difference is seen in PTE and not in SE; see table 7.2.

Thereafter, special tests called multiple comparison procedures were used to determine which means are significantly different from each other. Many multiple comparison procedures are available. They differ 
Table 7.1. Tests of Significance: Multivariate

\begin{tabular}{llcc}
\hline & Value & $F$-value & $p$-value \\
\hline Pillai's Trace & 0.77 & 4.32 & 0.002 \\
Wilks'Lambda & 0.923 & 4.38 & 0.002 \\
Hotelling's Trace & 0.83 & 4.44 & 0.002 \\
Roy's Largest Root & 0.82 & 8.78 & 0.000 \\
\hline
\end{tabular}

Table 7.2. Tests of Significance: Univariate

\begin{tabular}{llcrcrr}
\hline Source & DV & $\begin{array}{l}\text { Sum of } \\
\text { Square }\end{array}$ & df & $\begin{array}{l}\text { Mean } \\
\text { square }\end{array}$ & $F$-value & $p$-value \\
\hline Intercept & VRS (PTE) & 74.40 & 1 & 74.40 & 2562.03 & 0.000 \\
& Scale (SE) & 146.30 & 1 & 146.30 & 9658.00 & 0.000 \\
Region & VRS (PTE) & 0.37 & 2 & 0.185 & 6.38 & 0.002 \\
& Scale (SE) & 1.005 & 2 & 5.02 & 0.33 & 0.718 \\
Error & VRS (PTE) & 6.24 & 215 & 2.90 & & \\
& Scale (SE) & 3.25 & 215 & 1.51 & & \\
\hline
\end{tabular}

Table 7.3. Multiple Comparison Procedures: Scheffe's Test

\begin{tabular}{lccccl}
\hline $\begin{array}{l}\text { Dependent } \\
\text { variable }\end{array}$ & Region $(I)$ & Region $(J)$ & $\begin{array}{l}\text { Mean } \\
\text { difference }(I-J)\end{array}$ & $\begin{array}{l}\text { Standard } \\
\text { error }\end{array}$ & $p$-value \\
\hline VRS (PTE) & 1 & 2 & 3.89 & 2.94 & 0.42 \\
& 2 & 3 & 9.55 & 2.68 & 0.002 \\
Scale (SE) & 1 & 2 & 5.66 & 2.95 & 0.162 \\
& 2 & 3 & -1.06 & 2.12 & 0.95 \\
& 2 & 3 & -1.67 & 2.94 & 0.86 \\
& & 3 & & & 0.73 \\
\hline
\end{tabular}

in how they adjust the observed significance level. In this study, Scheffe's test has been used; see table 7.3. Norusis (1998) states, 'this test is conservative for pair-wise comparisons of means and requires larger differences between means for significance than the other multiple comparison tests'.

High-income countries (group 1) show significantly higher PTE than low-income countries (group 3). Hence, going by the global advantage hypothesis, banks in developing countries where banking structures are less efficient could be targeted by large banks in developed countries for 
possible expansion of business taking advantage of the liberalized entry regulations now offered by these countries. Many efficient large banks in developed countries already seem to be doing this. For example, as stated by the Indian Banks' Association (1999), in India the number of foreign banks and their branches have increased by 13, from 29 (1996) to 42 (1998) in just two years. The Asian Banker (1999) report shows that 17 cross border M\&As took place in South East Asia from January 1998 - August 1999. Going by the results of this study, in coming years, a surge in M\& A's in the region is expected.

\section{Conclusion}

In this study, the efficiency of large commercial banks in Asia and the Pacific region was investigated using DEA. It was found that as the national frontier is expanded to regional frontier, the efficiency scores decline. Regression was used to identify the factors that influence efficiency. It was found that environmental variables have significant influence on efficiency scores. Hence, banks expanding business across borders have to take this in to account and devise appropriate managerial strategies to remain efficient in a foreign country. Next, the efficiency scores of banks with and without the inclusion of environmental variables were estimated. This again confirms that environmental variables significantly affect efficiency estimates. When the three groups of countries were compared, using MANOVA, the developed countries showed pure technical efficiency score significantly higher than the less developed countries. Hence, going by the global advantage hypothesis a rise in the M\&As of banks in this region is expected.

\section{References}

Allen, L. and Rai, A. 1996. Operational efficiency in banking: An international comparison. Journal of Banking and Finance 20: 655-672.

Aly, H. Y.; Grabowski, R.; Pasurka, C. and Rangan, N. 1990. Technical, scale and allocative efficiencies in U.S. banking: An empirical investigation. Review of Economics and Statistics 72: 211-218.

Aly, A. I. and Seiford, L. M. 1993. The mathematical programming approach to efficiency analysis. In H. O. Fried, C .A .K. Lovell, and S .S .Schmidt (eds). The Measurement of Productive Efficiency; Techniques and Applications. Oxford: Oxford University Press. 
Asian Banker. 1999. Mergers and acquisition special report. Singapore: The Asian Banker Publishing.

Asia Week. 2000. The Asia week financial 500: The region's largest banks 2000. Asia Week 36: 82-99.

Avkiran, N. K. 1999. The evidence of efficiency gains: The role of mergers and the benefits to the public. Journal of Banking and Finance 23: 991-1013.

Ayadi, O. F.; Adebayo, A. O. and Omolehinwa, E. 1998. Bank performance measurement in a developing economy: An application of data envelopment analysis. Managerial Finance 7: 5-16.

Banker, R. D.; Charnes, A.; Cooper, W. W.; Swarts, J.; Thomas, D. A. 1989. An introduction to data envelopment analysis with some of its models and their uses. In J. L. Chan and J. M. Patton (eds.) Research in Governmental and Non Profit Accounting 5. Greenwich CN: Jai Press.

Bauer, P. W. 1990. Recent developments in the econometric estimation of frontiers. Journal of Econometrics 46: 39-56.

Bekaert, G.; Harvey, C. R. and Ng, A. 2002. Market integration and contagion. Working Paper.

Berg, S.; Forsund, F.; Hjalmarsson, L.; Souminen, M. 1993. Banking efficiency in the Nordic countries. Journal of Banking and Finance 17: 371-388.

Berg, S. A.; Bukh, P. N. D. and Forusnd, F. R. 1995. Banking efficiency in the Nordic countries: A four-country malmquist index analysis. Working paper. Aarhus: University of Aarhus.

Bergendahl, G. 1995. DEA and benchmarks for Nordic banks. Working paper. Gothenburg: Gothenburg University.

Berger, A. N.; DeYoung, R.; Genay, H. and Udell, G. F. 2000. Globalization of financial institutions: Evidence from cross-border banking performance, SSRN Electronic Paper Collection.

Berger, A. N. and Humphrey, D. B. 1997. Efficiency of financial institutions: International survey and directions for future research. European Journal of Operational Research 2: 175-212.

Buch, C. M. and Heinrich, R. P. 2001. Capital flows to transition economies: How risky is financial integration? Working Paper.

Charnes, A.; Cooper, W .W. and Rhodes, E. 1978. Measuring efficiency of decision-making units. European Journal of Operations Research 2: 429-44.

Coelli, T. 1996. A Guide to DEAP Version 2.1, A data envelopment analysis (computer) program. Working paper. Armidale: CEPA.

Chen, T. Y. and Yeh, T. L. 1998. A study of efficiency evaluation in Taiwan's banks. International Journal of Service Industry Management 5: 402-415.

Dietsch, M. and Lozano-Vivas, A. 2000. How the environment determines banking efficiency: A comparison between French and Spanish industries. Journal of Banking and Finance 24: 985-1004.

Dungey, M. and Martin, V. L. 2001. Contagion across financial markets: An empirical assessment. Working paper. Canberra: Australian National 
University.

Fecher, F. and Pestieau, P. 1993. Efficiency and competition in O.E.C.D. financial services. In: H.O.Fried, C.A.K. Lovell, S.S. Schimidt. (eds). The Measurement of Productive Efficiency Techniques and Applications. Oxford: Oxford University Press.

Ferrier, G. 1997. Ownership type, property rights and relative efficiency. In A. Charnes, W. Cooper, A. Y. Lewin, and L. M. Seiford (eds). Data Envelopment Analysis: Theory, Methodology and Applications. Boston: Kluwer.

Ferrier, G. and Lovell, C. A. K. 1990. Measuring cost efficiency in banking: Econometric and linear programming evidence. Journal of Econometrics 46: 229-45

Field, K. 1990. Production efficiency of British building societies. Applied Economics 22: 415-425.

Financial System Inquiry. 1997. The Financial System Inquiry Final Report. Canberra.: AGPS

Fried, H. O. and Lovell, C. A. K. 1994. Measuring efficiency and evaluating performance. In Steering Committee for the Review of Commonwealth/State Service Provision (eds). Data Envelopment Analysis: a Technique for Measuring the Efficiency of Government Service Delivery. Canberra: AGPS.

Fried, H. O.; Lovell, C. A. K.; Eackaut, P. V., 1993. Evaluating the performance of U.S. credit unions. Journal of Banking and Finance 17: 251-265.

Hair, J. F.; Anderson, R. E.; Tatham, R. L.; Black, W.C. 1998. Multivariate Data Analysis. Englewood Cliffs, N. J., : Prentice Hall.

Hancock, D. 1986. A model of the financial firm with imperfect asset and deposit elasticities. Journal of Banking and Finance 10:37-54.

Indian Banks' Association. 1999. Indian Banking Year Book 1998. Mumbai: Indian Banks' Association.

Kwast, M. L. and Rose, J. T. 1982. Pricing, operating efficiency and bank profitability among large commercial banks. Journal of Banking and Finance 6: 233-254.

Lucey, B. 1995. Profits, efficiency and Irish banks. Journal of the Statistical and Social Inquiry Society of Ireland 24: 24-38.

Miller, S. M. and Noulas, A. G. 1996. The technical efficiency of large bank production. Journal of Banking and Finance 20: 495-509.

Molyneux, P.; Altunbas, Y.; and Gardener, E. 1996. Efficiency in European Banking. Chichester: John Wiley.

Norusis, M. J. 1993. SPSS for Windows Base System User's Guide Release 6.0. Chicago: SPSS.

Pastor, J. M.; Perez, F. and Quesada, J. 1997. Efficiency analysis in banking firms: An international comparison. European Journal of Operational Research 2: 395-407. 
Seiford, L. M. and Thrall, R. M. 1990. Recent developments in DEA: The mathematical programming approach to frontier analysis. Journal of Econometrics 46: 7-38.

Sherman, D. and Gold, F. 1985. Branch operating efficiency: Evaluation with data envelopment analysis. Journal of Banking and Finance 9: 297-315.

Stevens, James. 1992. Applied Multivariate Statistics for the Social Sciences. Hillsdale: Lawrence.

Tabachnick, B. G. and Fidell L.S. 1996. Using Multivariate Statistics. Boston: Harper Collins.

World Bank. 2000. Entering the 21st Century World Development Report. Washington: The World Bank. 